\title{
THE EFFECT OF INDIVIDUAL MORALITY AND INTERNAL CONTROL ON THE PROPENSITY TO COMMIT FRAUD: EVIDENCE FROM LOCAL GOVERNMENTS
}

\author{
Novita Puspasari \\ Faculty of Economics and Business, Universitas Jenderal Soedirman \\ (novita.puspasari@yahoo.com)

\section{Eko Suwardi} \\ Faculty of Economics and Business, Universitas Gadjah Mada \\ (e.suwardi@ugm.ac.id)
}

\begin{abstract}
This paper aims to examine the influence of individual morality and internal controls on individuals' propensity to commit accounting fraud at the local government level. This is a quasiexperimental research paper. Individual morality and internal controls are hypothesized to be having an interaction with each other in influencing the propensity to commit accounting fraud. Individuals who have low levels of moral principles are hypothesized to have the tendency to commit accounting fraud in the absence of any internal controls. To test this, a $2 \times 2$ factorial experiment was conducted involving 57 students from the Masters in Economics Development programme at Gadjah Mada University. The result shows that there is an interaction between individual morality and internal controls. The absence of internal controls does not cause an individual with high moral principles to commit accounting fraud. However, individuals with low morality levels tend to commit accounting fraud when internal controls are absent.
\end{abstract}

Keywords: Accounting Fraud, Morality, Internal Controls, Local Government.

\section{INTRODUCTION}

The financial system is no longer immune since the reformation of our country. In the financial perspective, particularly in government institutions, the reformation has created the legal basis for the construction of some regulations regarding the autonomous regions and their introduction of technologies that speed up the process of organization, and the implementation of systems based on good governance. Good governance refers to the attitudes, ethics, practices and values of society. One of the main pillars of good governance is its accountability system. Concerning the public sector's reformation in Indonesia, there is a strong demand for accountability by public institutions, both national and local. Accountability can be defined as the responsibility for the success or failure to implement the mission of the organization, which is to achieve the vision that has been set for it. One form of governments' accountability to its citizen is its financial statements.

Sadly, the decentralization of financial management in Indonesia has allowed acts of corruption to now occur at the local level. A study by Indonesian Corruption Watch (ICW) in 2014 found that 43 district heads in Indonesia were sued for corruption. Based on PUKAT UGM's report in 2013, corruption in Indonesia is dominated by government employees. Another research study from the Central Statistics Agency (BPS) in 2013 discovered that the anticorruption index declined, but at the same time, the corruption index in Indonesia increased. In fact, Indonesia is a country with a high corruption rating on the world scale, ranked at number 107 of 183 in the corruption index (Transparency International, 2014). Research by Gaviria (2001) showed that accounting fraud is influenced by the level of corruption in a country. 
One data set that indicates accounting fraud in financial statements is the audit result of the Government Audit Board (Badan Pemeriksa Keuangan) for the Local Government Financial Statement (LKPD) in 2013. An unqualified opinion is the best opinion given by the BPK for the local governments or institutions with good financial statements. In 2013, of the 456 local governments audited, only 34 (or 7.4 percent) of local governments received this unqualified opinion. This shows that the quality of financial reporting in the Indonesian government system is not good enough. If the reporting quality is not good enough, the accountability for regional economic resources management is questionable. In the first quarter of 2014, BPK examined 670 statements from various areas of the government system. There were 14,854 cases of non-compliance worth Rp30.87 trillion.

According to Wells (2007), accounting fraud refers to accounting errors made intentionally with the purpose of misleading the readers/users of the financial statements. The fraud is done with a negative motivation to take advantage of individuals or certain parties. According to the Association of Certified Fraud Examiners (ACFE) in 2013, accounting fraud can be classified into three types: Fraud in the financial statements, the misappropriation of assets, and corruption. Based on the investigations above, such types of fraud are reported in Indonesia.

In 1973, Donald Cressey, an American criminologist and sociologist stated that there are three factors that cause accounting fraud, namely: opportunity, rationalization, and incentive/pressure. These three factors are called the fraud triangle. In 1984, Albrecht, an accounting doctoral candidate, proposed a fraud scale which contains three factors that lead to the occurrence of fraud, which are the situational pressure, the opportunity to commit fraud and personal integrity. The study of Albrecht et al. (1984) reinforces Cressey's earlier study. Albrecht replaced the rationalization factor with personal integrity to make it more observable. Personal integrity refers to a personal code of ethics of an individual. This integrity can be observed through the theory of moral development, as used in ethics research.

Ramamoorti (2008) stated that the rationalization and pressure are causal factors of accounting fraud, based on the psychological condition of the perpetrator. Dorminey et al. (2011) stated that the rationalization and pressure factors are characteristics that cannot be observed because it is impossible to know what is on the mind of the perpetrator when committing accounting fraud.

Accounting fraud is closely related to ethics. It is also an illegal act. According to Hernandez and Groot (2007), accounting fraud is illegal behaviour that is generally a part of unethical behaviour; therefore there are laws that must be implemented as part of the efforts to enforce moral standards. Research from Hernandez and Groot (2007) found that ethics and the accounting control's environment are vital variables relating to the tendency of someone to commit accounting fraud. Albrecht and Albrecht (2004) pronounced that the personal integrity factors in the fraud scale refer to a personal code of ethics possessed by each individual.

Several studies in the field of ethics (Arnold \& Ponemon, 1991; Welton, et al. 1994; and Liyanarachi \& Newdick, 2009) use the moral development theory to observe individuals' tendencies to conduct an action. The notion that is commonly used is the theory of Kohlberg's level of moral reasoning. Knowing one's level of moral reasoning would be the foundation to determine the tendency of individuals to perform a certain action, specifically with regard to ethical dilemmas

Welton et al. (1994) states that an individual's ability to resolve ethical dilemmas is influenced by the level of his moral reasoning. Wilopo's research (2006) found that individuals with high levels of moral reasoning are less likely to attempt accounting fraud. Bernardi (1994) and Ponemon (1993), as cited in Moroney, and McDevitt (2008), found that the higher the level of one's morality is, the more sensitive that person is to ethical issues. 
In addition to the rationalization that is closely related to ethics, another factor that causes accounting fraud is opportunity. One of the sources of opportunity is weak internal controls. Coram et al. (2008) explained that an organization which has a strong internal audit function will be able to detect accounting fraud. Research from Hogan et al. (2008) found that auditors play a significant role in reducing the opportunities for accounting fraud. Research into local governments conducted by Puspasari (2009) found that the heads of districts tend to commit fraud when the internal controls are not effective.

This study elaborates on the theories for accounting fraud and ethics in the context of local governments in Indonesia. Based on the data from BPS, local governments are the most corrupt institutions in Indonesia. Individual levels of morality (high and low) and the elements of the organization's internal controls (their presence or absence) are the factors that are examined as the causes of the accounting fraud by this research.

\section{LITERATURE STUDY AND HYPOTHESES DEVELOPMENT}

\section{Accounting Fraud}

In 2013, the Association of Certified Fraud Examiners (ACFE), one of the associations in the United States that puts a lot of effort into preventing and reducing fraud, categorize fraud into three groups: financial statement fraud, asset misappropriation, and corruption. In 2001, the Indonesian Institute of Accountants (IAI) described accounting fraud as: (1) misstatements, arising from a fraudulent financial reporting misstatement or omission, is swindling to manipulate a financial report to deceive its users, (2) misstatements, arising from the improper treatment of assets (often referred to misuse or embezzlement), relating to the theft of said assets from entities that does not result in financial statements being presented in accordance with the Generally Accepted Accounting Principles (GAAP) in Indonesia. The misappropriation of assets can be done in various ways, including embezzlement of the receipts for goods/money, property theft, or actions which cause an entity to pay for goods or services that are never received by the entity. The misappropriation of assets can be accompanied by a note or a document that has been falsified or is deliberately misleading, and can be related to one or more individuals among employees or third parties.

In the fraud triangle, there are three factors that cause accounting fraud: rationalization, pressure and opportunity. In the fraud scale, there are three factors that lead to accounting fraud: situational pressure, the opportunity to conduct fraud, and how individuals rationalize something called personal integrity. Albrecht and Albrecht (2004) replaced this rationalization factor with personal integrity in order for it to be observable. Through personal integrity, the observation of individual decisions and the decision-making process would be closer to the goal of finding ethical decision making. According to Albrecht and Albrecht (2004), a violation of ethics, honesty and responsibility are at the core of accounting fraud. Ethical problems caused by rationalization, and with some expansion, the pressure factor, could be associated with fraud by looking at the condition of the individuals who perform acts of fraud when considering the truth or not of such allegations.

\section{Moral reasoning}

One of the theories of moral development that is widely used in ethics research is Kohlberg's model. Kohlberg (1969), as cited in McPhail and Walters (2009), stated that morals develop through three stages, namely the preconventional, conventional, and post-conventional stages. Welton et al. (1994) stated that an individual's ability to resolve ethical dilemmas is influenced by their level of moral reasoning. The results of several studies presented by Liyanarachi \& Newdick (2009) showed that the level of an individual's moral reasoning will affect their ethical behavior. People with a low level of moral reasoning behave differently to people who have a high level of moral reasoning, when facing ethical dilemmas. 
According to Rest (2000), the higher a person's level of moral reasoning is, the more likely they will be to do the 'right thing'.

In the lowest stage (pre-conventional), an individual will perform an act because they feel afraid of the law/rules. In addition, an individual at this moral level will also see their personal interests as the main reason for taking this action. In the second stage (conventional), the individual will base his/her actions on the approval of friends and family, and also on the norms that exist in the community. At the highest stage (post-conventional), the individual takes action with regard to the interests of others and such actions are based on universal laws.

According to Welton et al. (1994), in every stage of Kohlberg, individuals have their own views about what is 'the right thing'. Individuals in stage one feel that the right thing is what is in the interests of the individual. Individuals in stage 2 assume that the right thing is the result of the exchange of the draw and peer or family approvals. Individuals in stage 3 feel that the right thing relates to the expectations of trust, loyalty, and respect from friends and family. Individuals in stage 4 assume that the right thing is to make a contribution to their society, group or institution. Individuals in stage 5 and stage 6 assume that truth is based on the principle of ethical principles, the equality of human rights and dignity as a living being.

\section{Internal Control}

Coram et al. (2008) explained that an organization which has an internal audit function will be able to detect accounting fraud. Hogan et al. (2008) discussed the role of auditors in reducing the opportunity factor for accounting fraud. According to Bastian (2006), accounting controls are part of the internal control system, including organizational structures, methods, and measurements, which are coordinated primarily to keep the wealth of the organization, as well as checking the accuracy and reliability of the accounting data.

According to Arens and Loebbecke (1996), there are five elements of internal controls that should be owned by the organization. Those elements are: control of the environment, risk determination by the management, the accounting information systems, communications, control activities and monitoring. Meanwhile, according to Mulyadi (1998) there are four basic elements that need to be considered, namely:

1. The organizational structure that separates the functional responsibilities of the firm.

2. An authority system and recording procedures that provides adequate protection to the assets, debts, income and expenses.

3. The establishment of healthy practices for carrying out the duties and functions within the organization.

4. Employees whose qualities are in accordance with their responsibilities.

Boynton and Johnson (2006) defined control activities as policies and procedures that help ensure that management's orders have been actioned. Controls help ensure that the necessary actions are taken with regard to the risks to the achievement of the organizational goals. The definition of an internal control system, according to Peraturan Pemerintah No. 60/2008 on Satuan Pengawas Internal Pemerintah (SPIP) is:

A system of internal control is a process that is integral to the actions and activities carried out continuously by the management and all employees to provide reasonable assurance on the achievement of the objectives of the organization through effective and efficient management, the reliability of the financial reporting, the safeguarding of state assets, and compliance with the laws and regulations.

Internal control is the critical factor to make sure of the financial accountability of local government institutions. Each Satuan Kerja Perangkat Daerah (SKPD) receives and uses a budget for running its duties and functions, therefore, it has an obligation to make a financial statement detailing its use of the budget. The financial accountability of the government agencies of districts/cities is an embodiment of the accountability of the government agency for the implementation of the regional budget in running the programmes and activities necessary 
to carry out the mission of the organization, in order to achieve the goals and objectives that have been set for it.

\section{Hypothesis}

The American Institute of Certified Public Accountants (2009) explained that internal controls are very important, among other things, to provide protection for the entity against human weaknesses and to reduce the possibility of errors or actions that do not comply with the rules. Coram et al. (2008) explained that an organization which has an internal audit function will be able to detect accounting fraud. Research from Hogan et al. (2008) discussed the role of auditors in reducing the opportunity factor for accounting fraud. An internal control system, in order to function properly, needs an element of internal control. To achieve effective, efficient, transparent, and accountable financial management, according to BPK (2013) there must be control over the implementation of government activities by applying the elements of internal control. According to Lovell (1997), the rules in an organization are a form of internal controls that serve as a tool to ensure the organizational goals are achieved. Internal control is one of the factors that will be examined as the cause of accounting fraud in this research. Coram et al. (2008) found that organizations that have an internal audit function are able to detect and report accounting fraud themselves. Hogan et al. (2008) found that internal auditors play an important role in reducing the chance factor in accounting fraud.

Another factor causing accounting fraud that will be examined in this research is the ethical factor that is closely related to an individual's morality. Welton (1994) stated that an individual's ability to resolve ethical dilemmas is influenced by their level of moral reasoning. The results of several studies presented by Liyanarachi and Newdick (2009) showed that the levels of moral reasoning of individuals will affect their ethical behaviour. People with a low level of moral reasoning behave differently to people who have a higher level of moral reasoning, when facing ethical dilemmas. By their actions, those who have a low level of moral reasoning tend to do things that benefit them, and avoid things that can lead to legal sanctions.

This study also argues that an individual's morality will affect that person's propensity to commit accounting fraud. That is, the higher the stage of an individual's morality (post-conventional stages), the more the individual pays attention to the wider interests and universal needs, rather than mere organizational interests, and especially the interests of the individual. Thus, the higher the morality of the individual is, the more he/she will try to avoid the tendency to commit accounting fraud.

Individuals with higher levels of moral reasoning behind their actions will consider the interests of the people around them, and base their actions on moral principles, and then the presence or absence of elements of internal control would not make them attempt accounting fraud that would be detrimental to their organization and society. According to Graham (1995) and Patterson (2001), as cited in Moroney and McDevitt (2008), individuals with higher levels of moral reasoning for their actions will be steered by the principles of universal morality.

A situation where there is either the presence or absence of internal controls can cause individuals with low moral levels to perform, or not to perform, accounting fraud. However, for individuals with high moral principles, the presence or absence of such internal control elements in an organization will not make them perform accounting fraud, since that would be detrimental to the organization and society. Based on this, the authors formulate our first hypothesis:

$\mathrm{H}_{1}$. The condition of the internal control elements affects the relationship between the levels of public sector managers' morals, and their tendency to commit accounting fraud.

In the fraud scale, when situational pressures and opportunities to commit fraud are high and personal integrity is low, the possibility of committing fraud is very high. The opportunity here is provided by the condition of the internal 
controls in the organization. According to Albrecht and Albrecht (2004), one of the motivations for individuals to perform accounting fraud is a desire for personal gain.

In the absence of the element of internal controls within an organization, individuals with lower levels of moral reasoning tend to exploit these conditions for their personal use (selfinterest), for example, by actions relating to accounting fraud. These conditions correspond to those in the pre-conventional level of Kohlberg's levels, where individuals who have low levels of moral reasoning have, as their main motivation, fraud for gain and for their personal use (in accordance with stage two Kohlberg). Meanwhile, individuals with higher levels of reasoning, when facing the absence of internal control elements in their organization, will not perform unethical accounting fraud, as that would bring losses to many parties.

In Kohlberg's moral levels, obeying the existing rules to avoid certain penalties is included in the lower stages (the preconventional level). Individuals with low moral reasoning, when faced with the presence of internal controls, are less likely to commit accounting fraud because they fear their deeds will be detected by the organization's internal controls, and they will receive legal sanctions. This is in accordance with the stage one model of Kohlberg's moral development. There is empirical evidence from Graham (1995) and Patterson (2001), as cited in Moroney and McDevitt (2008), who found that individuals with lower levels of moral reasoning are more regulatory and legal sanctions' oriented. Based on this, the second and third hypotheses are:

$\mathrm{H}_{2}$. In the absence of internal control elements, public sector managers who have low levels of moral reasoning tend to commit accounting fraud, compared to public sector managers who have higher levels of moral reasoning.

$\mathrm{H}_{3}$. Public sector managers with lower levels of moral reasoning tend to commit accounting fraud when faced with the absence of internal control elements, rather than when the internal control elements are present.

\section{METHOD}

\section{Procedure and Task Participants}

The researchers created a series of procedures to be undertaken by the participants, allowing the experiment to be run according to the planned manipulation. Each participant was given an envelope. Inside the envelope were two assignments. The first assignment was to measure the individual's moral reasoning. In this assignment, the participant was asked to read four scenarios featuring ethical dilemmas, and to give their judgement on each scenario. The instrument for moral reasoning was developed from Rest (2000). Their judgement scores will be used to measure their level of moral reasoning.

The second assignment was to measure their tendency to commit accounting fraud. The participant was given a scenario that contains information about their role in the experiment. In this case, the respondent is given the scenario that he/she is a manager in local government (Head of Department X). In this scenario, the participant is given an understanding of their background as the head of Department $\mathrm{X}$ and the conditions that exist in the organization they lead. In this assignment, there are three types of fraud listed: asset misappropriation, fraudulent financial reporting and corruption. If the participant decides to conduct a fraudulent tender, it means he/she is committing those three forms of fraud.

The experimental scenario in the first assignment uses the third-person context as suggested by Rest (1986), as cited in Liyanarachi and Newdick (2009), for research into ethics. This is reinforced by ethics studies conducted by Arnold and Ponemon (1991), and Bernardi and Guptill (2008), which also used the third-person context.

There were two manipulation check questions in the experiment. Both questions were about the working condition in Department $\mathrm{X}$ as illustrated in the scenario. Manipulation checks aim to measure whether participants truly read 
the complete scenario or not. If participants were wrong with their answers to those two questions, they were eliminated. If they only answered one question correctly, they were still counted as experiment participants.

\section{Participants}

Participants in this study were masters degree students in the Economic Development Programme (MEP) at UGM, and used as surrogates for public sector managers (heads of local government institutions/head of the SKPD). The public sector manager (head of the SKPD) is the highest decision-maker in that institution. In addition, under Permendagri 21 article 10, the head of the SKPD is responsible for the institution's financial statements.

The reasons for selecting students as surrogates were based on Betts' (2009) research. That research found that perpetrators with a masters education level (S-2) committed fraud more frequently than those who only possess a graduate level degree (S-1). The second reason was the S-2 students of MEP UGM have a greater number of government lectures than other economic majors do. The third and the strongest reason was that all of the participants were government employees. They already had a basic understanding about the government's circumstances. Therefore, they were expected to understand the public sector managers' characteristics in the experimental scenario. A total of 70 students participated in this experiment.

\section{Experimental Design}

This study used a $2 \times 2$ factorial experimental design to test the influence of individual morality and internal control on accounting fraud. The dependent variable in this study is accounting fraud, while the independent variable is individual morality (high and low levels of morals) and internal controls (the presence or absence of internal controls).

The researchers observed the tendency of the individuals to commit accounting fraud by dividing the participants into four groups: (1)
Group 1, the group with high morals and the presence of internal controls, (2) Group 2, the group with high morals but the absence of internal controls, (3) Group 3, the group with low morals and the presence of internal controls, and (4) Group 4, the group with low morals and the absence of internal controls. The experimental design can be seen in Table 1 .

Table 1. 2x2 Experiment's Design

\begin{tabular}{ccc}
\hline \multirow{2}{*}{$\begin{array}{c}\text { Moral Reasoning } \\
\text { Level }\end{array}$} & \multicolumn{2}{c}{ Internal Control Element } \\
\cline { 2 - 3 } High & Presence & Absence \\
\hline Low & Group 1 & Group 2 \\
\hline
\end{tabular}

Source: Experiment's design in the article

\section{Variables and Research Instruments}

In this study, there is one dependent variable, the tendency to commit accounting fraud. According to the ACFE (2013), there are three types of accounting fraud: financial statement fraud, the misappropriation of assets, and corruption. The accounting fraud variable is measured by asking the participants to give their opinions on a question representing three types of accounting fraud. The participants answer the question after reading the experimental scenario. A Likert scale of 1-7 is used to measure the response of the participants. The higher the participants score, the more likely they are to commit fraud.

The independent variables in this study are individual morality (high level and low levels of morality) and internal controls (the presence or absence of internal controls). The measurement of individual morality comes from the moral measurement model developed by Rest (2000) in the form of the Defining Issues Test (DIT). This instrument shapes cases with an ethical dilemma. Individual morality is measured by an instrument developed from Rest (2000) to measure the level of moral reasoning of individuals through four scenarios with ethical dilemmas. The level of moral reasoning is divided into two categories, low and high, using the median value of the P-score from the total sample. 
The existence of the elements of internal control is illustrated through the application of authority and responsibility in the organization, its periodic transaction records, the presence of physical controls, a comprehensive accounting system, as well as periodic monitoring and evaluations. The absence of internal control elements in the scenario are depicted in the form of a lack of any implementation authority and clear responsibility in the organization, the recording of transactions which are not periodic, the lack of physical controls, an accounting system that cannot record all the operations of the agency and the lack of periodic monitoring and evaluations of the agency. To develop the instrument, the researchers discussed these matters with some government employees who are familiar with these issues. After the instrument was created, the researchers tested it by conducting a pilot test. Some refinements were made after this pilot test.

\section{RESULTS}

\section{Manipulation Check}

A manipulation check was done by testing the participants to determine the right or wrong of two questions. The first question was about the participants' task as the Head of Department $\mathrm{X}$. The second question related to elements of the internal controls in Institution $\mathrm{X}$. The manipulation checks aimed to measure whether the participants truly read the whole of the scenario or not. If participants gave the wrong answers to those two questions, they were eliminated. If they only answered one question incorrectly, they were still counted as a participant. The result of the analysis indicates that, for the manipulation check of the 70 participants, only a total of 57 participants (81.4 percent) passed the manipulation check. Thirteen participants (18.6 percent) did not pass it.

\section{Experimental results}

The purpose of this study is to compare the morality among groups. Analysis of Variance (ANOVA) is a suitable statistical test to use here. ANOVA can test more than one treatment and this is its major advantage compared to the $t-$ test. A normality test is performed to determine whether the data in this study is normally distributed. The test results from KolmogorovSmirnov's normality test show the signification (over 0.005). From that result, it can be stated that the data are normally distributed, and meets one of the ANOVA's assumptions. Tests for the homogeneity of the variance were conducted to determine whether the four groups (Groups 1, 2, 3 , and 4) have the same variance. Statistical analysis showed a Levene statistic value of 0.176 (over 0.005). This suggests that each group of subjects did fulfil the same variant and have met the assumptions of ANOVA (Hair et al., 2006), while the ANOVA between the groups showed a significant p-value of 0.000 . These results indicate that there are significant differences between the groups. To answer the hypotheses, the following tables will show the levels of the individuals' moral influence and the elements of internal control over their accounting fraud propensities, and a statistical description of the differences between the groups.

Table 2. The Effect of Morality Levels and the Internal Control Elements on the Propensity to Commit Fraud

\begin{tabular}{cccccc}
\hline Source & df & Mean Square & F & Sig. & Partial Eta Squared \\
\hline Corrected model & 3 & 15,798 & 22,338 & 0.000 & 0.558 \\
Intercept & 1 & 264,221 & 373,603 & 0.000 & 0.876 \\
Morality & 1 & 22,078 & 31,217 & 0.000 & 0.371 \\
Elemen PI & 1 & 9,105 & 12,874 & 0.001 & 0.195 \\
Morality*ElemenPI & 1 & 16,179 & 22,877 & 0.000 & 0.301 \\
Error & 53 & & & & \\
Adj.RSquared $=0.533$ & & & & & \\
\hline
\end{tabular}

Source: ANOVA's data 
Table 3. Group Statistics Description

\begin{tabular}{ccc}
\hline $\begin{array}{c}\text { Moral } \\
\text { Reasoning } \\
\text { Level }\end{array}$ & \multicolumn{2}{c}{ Internal Control Element } \\
\cline { 2 - 3 } & Presence & Absence \\
\hline & Group 1 & Group 2 \\
& Mean=1.6667 & Mean=1.4000 \\
High & S.D. (0.81650) & S.D. (0.50709) \\
& $\mathrm{n}=15$ & $\mathrm{n}=15$ \\
& Group 3 & Group 4 \\
& Mean=1.8462 & Mean=3.7143 \\
& S.D. (0.89872) & S.D. (0.89258) \\
& $\mathrm{n}=13$ & $\mathrm{n}=14$ \\
\hline
\end{tabular}

Source: ANOVA's data

The first hypothesis states that the condition of the internal control elements will affect the relationship between the levels of public sector managers' morals and their tendency to commit accounting fraud. From Table 2 it can be seen that there is an interaction between the morality level and the elements of internal control ( $\mathrm{F}=$ 22,877 with a p-value of 0.000 ). Evidence of the strength of the effect of the interaction's variables indicates that there is interdependence between the morality levels of the individual with the condition of the internal control elements, thus the first hypothesis is supported.

The presence or absence of internal controls in an organization will make public sector managers with a certain level of morality tend to commit accounting fraud. Changes in the levels of the internal controls will have an impact on the likelihood of public sector managers with certain morality levels (high or low) performing accounting fraud. Table 3 shows the mean difference in each group with a certain level of morality and the condition of the elements of the internal controls. To determine the significant group mean difference, a post-hoc analysis was then performed.

Based on Table 3 and Table 4 of Tukey's tstatistics, the researchers compared the mean of Group 1 and 2 to see the effect of the internal controls on accounting fraud. From the comparison of the two groups they obtained a mean difference of 0.2667 with $p=0.821$. These results indicate that there is no significant difference between Group 1 and Group 2. This means that the presence or absence of internal controls does not affect the decision of public sector managers who have high morals to commit accounting fraud.

Table 4. Tukey t-statistics

\begin{tabular}{lccc}
\hline & $\begin{array}{c}\text { Mean } \\
\text { Difference } \\
(I-J)\end{array}$ & $\begin{array}{c}\text { Standard } \\
\text { Error }\end{array}$ & P-Value \\
\hline Group 1 and 2 & 0.2667 & 0.30708 & 0.821 \\
Group 4 and 2 & $2.3143^{*}$ & 0.31251 & 0.000 \\
Group 4 and 3 & $1.8681^{*}$ & 0.32391 & 0.000 \\
\hline
\end{tabular}

Source: ANOVA's data

The results of this study prove what is in the stages of moral development in Kohlberg's hierarchy. The higher the stage an individual's morality is at (the post-conventional stages), the more that individual pays attention to the interests of the broader world and society around $\mathrm{him} / \mathrm{her}$, rather than mere organizational interests, and especially personal interests. Public sector managers with high levels of morality tend not to commit accounting fraud under any circumstances.

Public sector managers with higher levels of moral reasoning for their actions will consider the interests of the people around them and their actions will be based on moral principles, rather than the presence or absence of the elements of internal control, and will not make them commit accounting fraud. They will not misuse their positions for their own benefit. The results of this study also strengthen the results of ethics studies previously conducted by Liyanarachi and Newdick (2009), Arnold and Ponemon (1991), Welton et al. (1994), Graham (1995) and Patterson (2001), as cited in Maroney and McDevitt (2008), that stated that individuals who have higher levels of moral reasoning will be more sensitive to ethical issues, so they will tend to act ethically.

The second hypothesis states that in the absence of internal control elements, public sector managers who have low levels of moral reasoning tend to commit accounting fraud, compared to public sector managers who have higher levels of moral reasoning. From Table 3 and Table 4, we compare between Group 4 and 
Group 2, which represents the hypothesis. From the comparison of the mean of both groups, a mean difference of 2.3143 is obtained with $\mathrm{p}=$ 0.000 . These results indicate that there are significant differences between Group 4 and Group 2. Public sector managers who have low levels of moral reasoning (Group 4) are more likely to commit accounting fraud compared to public sector managers who have a higher level of moral reasoning (Group 2), in the event there is no element of internal control. Thus, the third hypothesis is supported.

In the absence of internal controls within their organization, public sector managers with lower levels of moral reasoning will exploit these conditions for their personal use (selfinterest), by committing accounting fraud. This is consistent with the existing stage 2 in Kohlberg (the pre-conventional level), where individuals who have low levels of moral reasoning have the main motivation for their corruption being that it is done for their personal gain.

The third hypothesis states that public sector managers with lower levels of moral reasoning tend to commit accounting fraud when faced with the absence of internal control elements, rather than when they are present. Based on Table 3 and Table 4 of Tukey's t-statistics, we compare the mean of Groups 4 and 3 and obtain a mean difference of 1.8681 with $\mathrm{p}=0,000$. The mean for Group 3 was 0.89872 , which is lower than the mean of Group 4 (3.7857). This means that public sector managers with lower levels of moral reasoning in the absence of internal control elements (Group 4) tend to commit accounting fraud compared to public sector managers with lower levels of moral reasoning in the presence of internal control elements (Group 3), thus the fourth hypothesis is supported.

The results of this study also support the research of Graham (1995) and Patterson (2001), as cited in Maroney and McDevitt (2008), that found that individuals with low levels of reasoning are more regulatory and legally oriented because they do not want to be punished, so in the presence of internal controls, they will not attempt to carry out accounting fraud that would cause them to be punished if caught. The results of this study support the research of Maroney and McDevitt (2006), who found that regulations can be an effective deterrent to someone thinking about doing something that is not in accordance with the existing rules. According to Lovell (1997), the rules of an organization are a form of internal control that serves as a tool to ensure the organizational goals are achieved.

\section{DISCUSSION AND CONCLUSIONS}

The purpose of this study is to compare the propensity to commit accounting fraud among public sector managers who have low or high levels of moral reasoning in the presence or absence of internal control elements. The results of this study indicate that there are interactions between public sector managers' moral levels and the internal controls. Changes in one level will cause changes in their possibility of committing fraud. For example, changes in the level of morality or changes in the internal controls can make people who previously did not think about committing fraud become fraud perpetrators and vice versa. This is seen from the support for the first hypothesis.

Since controlling individual's moral reasoning is impossible, internal controls can be tools that are able to reduce the propensity to commit accounting fraud by individuals with a low level of moral reasoning. The results of the second and third hypothesis prove that in the presence of internal controls, public sector managers who have a low level of moral reasoning tend not to commit accounting fraud. In contrast, in the absence of such internal controls, public sector managers with lower levels of moral reasoning will tend to commit accounting fraud.

There are three important contributions by this research. First, each government institution is expected to have elements of internal control, because it is proven to be effective in preventing individuals with low morality levels from committing fraud. Second, this study will encourage other studies into fraud in government institutions to use the experimental method. So 
far, research into fraud in the government is very rare because it is considered sensitive. The experimental method can be used for this type of research. Third, the elaboration of interdisciplinary theories is needed to explain the phenomenon of fraud in the government.

There are several limitations to this study. Firstly, although all the respondents in this study are government employees, they are central government employees, not local government employees. This study aims to measure fraud in local governments. The characteristics of central and local government employees may be different. One suggestion for future research is for such a study to use respondents employed by the local governments in order to be closer to the real circumstance. Secondly, according to $\mathrm{Mc}$ Phail and Walters (2009), individual attributes such as moral maturity, age, gender and nationality also affect a person when he or she faces an ethical dilemma. This study only measures the individual's moral attribute. Future studies should measure other personal attributes such as age, gender, nationality or locality. Thirdly, this study does not go into our respondents backgrounds. Future research should consider this, as it may explain the respondents' reasons for giving the answers they do.

\section{REFERENCES}

Albrecht, S., K, Howe, and A. Tversky, eds, 1984. Deterring Fraud: The Internal Auditor's Perspective. Florida, United States: Institute of Internal Auditors Research Foundation.

Albrecht, S., W, and C. Albrecht, eds, 2004. Fraud Examination and Prevention. Australia: Thomson.

American Institute of Certified Public Accountants and Association of Certified Fraud Examiners, eds,, 2009. Managing The Business Risk of Fraud: A Practical Guide. United States: The Institute of Internal Auditors publisher.

Association of Certified Fraud Examiners, eds, 2013. Corporate Fraud Handbook: Prevention and Detection Fourth Edition. United States: John Wiley and Sons.
Arens, A. and Loebbecke, eds,, 1996. Auditing: Suatu Pengantar. Jakarta, Indonesia: Salemba Empat

Arnold, D. and L. Ponemon. 1991. "Internal auditors' perceptions of whistle-blowing and the influence of moral reasoning: an experiment". Auditing: A Journal of Practice \& Theory 10 (2), 1-15.

Badan Pemeriksa Keuangan Republik Indonesia, 2013. Available at http://www.bpk.go.id/ lkpp, accessed on July 4, 2014

Badan Pengawasan Keuangan dan Pembangunan, 2013. Available at http://www.bpkp. go.id/konten/2538/Informasi-yang-WajibTersedia-Setiap-Saat.bpkp, accessed on July 4, 2013

Badan Pusat Statistik, 2013. Available at http://bps.go.id/Subjek/view/id/34\#subjekVi ewTab3|accordion-daftar-subjek1, accessed on January 2, 2014.

Bastian, I, 2006. Akuntansi Sektor Publik: Suatu Pengantar. Jakarta, Indonesia: Erlangga.

Bernardi, R. and S. Guptill, 2008. "Social Desirability Response Bias, Gender and Factors Influencing Organizational Commitment: An International Study". Journal of Business Ethics, 81 (4), 797-809.

Betts, D, 2009. "The Psychology of Fraud: What Makes Employee Cross The Line?". ACFE Report. United States: Joint ACFE/ISACA.

Boynton, W., C. and R. N. Johnson, 2006 Modern Auditing Eight Edition. United States: John Wiley and Son. Inc.

Coram, P., C, Ferguson, and R. Moroney, 2008. "Internal Audit, Alternative Internal Audit Tructures and The Level of Misappropriation of Assets Fraud". Accounting and Finance, 48 (4), 543-559.

Cressey, D, eds,, 1973. Other People's Money: A Study in the Social Psychology of Embezzlement. Montclair, New Jersey. United States: Patterson Smith.

Dorminey, J., A. S. Fleming., M. J. Kranacher, and R. A. Riley. 2011. "Beyond The Fraud Triangle: Enhancing Deterrence of Economic Crimes". CPA Journal, 8 (7), 16-25. 
Gaviria, A., 2001. Assessing the Effects of Corruption and Crime on Firm Performance. Working Paper from Social Science Research Network.

Hair, J. F. 2006. Multivariate Data Analysis. New Jersey, United States: Prentice Hall.

Hernandez, J. R. and T. Groot, 2007. Corporate Fraud: Preventive Controls Which Lower Corporate Fraud. Amsterdan, The Netherlands: Amsterdam Research Centre in Accounting.

Hogan, C. E., Z. Rezaee., R. A. Riley., and U. K. Velury. 2008. "Financial Statement Fraud: Insights From The Academic Literature". Auditing: A Journal of Practice and Theory, 27(2), 231-252.

Ikatan Akuntan Indonesia. 2001. Standar Pemeriksaan Akuntan Publik. SA Seksi 316. Pertimbangan Atas Kecurangan Dalam Audit Laporan Keuangan. Jakarta: Ikatan Akuntan Indonesia.

2001. Standar Pemeriksaan Akuntan Publik. SA Seksi 319. Perimbangan Atas Pengendalian Internal Dalam Audit Laporan Keuangan. Jakarta: Ikatan Akuntan Indonesia.

Indonesian Corruption Watch, 2014. Available at http://www.antikorupsi.org/id/folder/ kajian, accessed on February 23, 2015

Liyanarachi, G dan C. Newdick, 2009. "The Impact of Moral Reasoning and Retaliation on Whistle-Blowing: New Zealand Evidence". Journal of Business Ethics, 89 (1), 37-57.

Lovell, A., 1997. "Some Thoughts on Kohlberg's Hierarchy of Moral Reasoning and Its Relevance for Accounting Theories of Control". Accounting Education, 6 (2) 147-162.

Maroney, J. J., and R. E. McDevitt, 2008. "The Effects of Moral Reasoning on Financial Reporting Decisions in a Post SarbanesOxley Environment". Behavioral Research of Accounting, 20 (2), 89-110.
Mc Phail, K. and D. Walters, 2009. Accounting and Business Ethics. London and New York: Routledge.

Mulyadi, 1998. Auditing Buku Satu. Jakarta: Salemba Empat

Peraturan Pemerintah No.80 tentang Sistem Pengendalian Intern Pemerintah, 2008. Available at www.inspektorat.lipi.go.id/ .../Peraturan-Pemerintah-tahun-2008-06008, accessed on June 23, 2014.

Puspasari, N, 2009. Pengaruh Asimetri Informasi, Keefektifan Pengendalian Internal dan Ketaatan Aturan Akuntansi terhadap Kecenderungan Melakukan Kecurangan Akuntansi Pada Kepala SKPD Kabupaten $X$ : Studi Kasus. Skripsi. Purwokerto: Universitas Jenderal Soedirman.

Pusat Kajian Anti Korupsi UGM, 2013. Available at http://pukatkorupsi.ugm.ac.id/ ?page_id $=3528$, accessed on November 4, 2014.

Ramamoorti, S, 2008. "The Psychology and Sociology of Fraud: Integrating the Behavioral Sciences Component Into Fraud and Forensic Accounting Curricula". Issues in Accounting Education, 23 (4), 521-533.

Rest, J. R, 2000. “A Neo-Kohlbergian Approach To Morality Research". Journal of Moral Education, 29 (4), 381-396.

Transparency International, 2014. Available at http://www.transparency.org/research/cpi/ov erview, accessed on January 30, 2015

Wells, J. T, 2007. Corporate Fraud Handbook: Prevention and Detection: Second Edition. United States: John Wiley and Sons Inc.

Welton, R. E., J, R, Davis and M. LaGroune, 1994. "Promoting The Moral Development Of Accounting Graduate Students". Accounting Education, 3 (1), 35-50.

Wilopo, 2006. Analisis Faktor-Faktor yang Berpengaruh Terhadap Kecenderungan Kecurangan Akuntansi: Studi pada Perusahaan Publik dan Badan Usaha Milik Negara (BUMN) di Indonesia. Simposium Nasional Akuntansi IX Padang: 23-26 Agustus 2006. 